Article

\title{
Spatial Characteristics of Edible Wild Fern Harvesting in Mountainous Villages in Northeastern Japan Using GPS Tracks
}

\author{
Toshiya Matsuura $^{1{ }^{*}}$, Ken Sugimura ${ }^{2}$, Asako Miyamoto ${ }^{1}$, Hiroshi Tanaka ${ }^{3}$ and \\ Nobuhiko Tanaka 4
}

1 Department of Forest Management, Forestry and Forest Products Research Institute, 1, Matsunosato, Tsukuba, Ibaraki 305-8687, Japan; E-Mail: asakom@affrc.go.jp

2 Research Planning and Coordination Department, Forestry and Forest Products Research Institute, 1, Matsunosato, Tsukuba, Ibaraki 305-8687, Japan; E-Mail: kensugi@affrc.go.jp

3 Principal Research Coordinator, Forestry and Forest Products Research Institute, 1, Matsunosato, Tsukuba, Ibaraki 305-8687, Japan; E-Mail: hirop@affrc.go.jp

4 School of Tourism, Tokai University, 2-28-4, Tomigaya, Shibuya-ku, Tokyo 151-8677, Japan; E-Mail: tanaka_nobuhiko@tokai-u.jp

* Author to whom correspondence should be addressed; E-Mail: matsuu50@affrc.go.jp; Tel.: +81-29-829-8314; Fax: +81-29-873-3799.

Received: 26 November 2013; in revised form: 12 February 2014 / Accepted: 13 February 2014 / Published: 20 February 2014

\begin{abstract}
Wild plants in forests provide valuable living resources for rural communities. The location where local people harvest various species is important to the wise use of forest ecosystem services. Using global positioning system (GPS) tracking of harvesters' activities as well as geographic information system (GIS) and a generalized linear model (GLM), this study analyzed the spatial differences among harvesting sites of three popular edible ferns, i.e., ostrich fern (Matteuccia struthiopteris), bracken (Pteridium aquilinum), and royal fern (Osmunda japonica), in mountainous villages of Northeastern Japan. The explanatory variables used were vegetation classes, terrain features, and proximity to roadways. The GLM yielded clear differences in harvesting sites among species that were affected by both the species' ecological characteristics and human behavior. Ostrich fern was harvested mainly in canopy openings along valley floors, whereas royal fern harvest sites were frequently located in snow avalanche scrublands. Bracken was mainly harvested in deforested areas or young conifer plantations. Whereas ostrich fern and bracken harvest sites were restricted by the accessibility from roadways, this was not the case for royal fern. Potential harvest sites of ferns were estimated with the highest value for bracken. Our
\end{abstract}


results suggest that local harvesters seriously consider various natural and anthropogenic factors to maintain effective and sustainable harvesting.

Keywords: generalized linear model; GIS; non-timber forest product; ecosystem services; Fukushima Prefecture

\section{Introduction}

The production of non-timber forest products (NTFP) are important ecosystem services, i.e., provisioning and cultural services, for people across the world in rural communities adjacent to forests [1-3]. For effective and sustainable harvest at the local scale, harvesters often conduct distinctively different harvesting activities for each target species, as each species requires specific environmental conditions [4,5]. Although such spatial patterns of harvesting activities are important for the wise use of forest landscapes, few studies have quantitatively analyzed these differences among various NTFP species [6]. This is due mainly to the difficulty in recording harvesting activities simultaneously conducted by many harvesters and in analyzing the effects of various natural and anthropogenic factors.

In recent decades, various small handheld GPS devices have become available, making it possible to easily track multiple animal or human movements concurrently. By recording both GPS tracks and types of activities together, it is possible to characterize the spatial patterns of different activities in the field. GIS and statistical models have also been widely used for analyzing the spatial characteristics of flora and fauna distribution from local to regional scales [7-9]. These studies have successfully described the effects of a variety of factors on species distribution and estimated potential species-distribution maps, both of which are useful for habitat conservation and management [10]. As NTFP harvest sites are generally influenced both by the ecological characteristics of each species and by human harvesting behavior, it is important to analyze both of these factors, which are indispensable for maintaining sustainable resource use. Although some studies have recorded harvesting activities by local people using GPS devices [11,12], their spatial characteristics have rarely been analyzed with statistical models, as attempted in this study.

In Japan, various edible wild plants and mushrooms are harvested annually, particularly in the northeastern archipelago, where cool-temperate forests dominate [12-16]. Edible wild ferns are representative of the species that have been widely harvested in Japan. This study examined the three most popular edible wild ferns in Japan, i.e., ostrich fern (Matteuccia struthiopteris), bracken (Pteridium aquilinum), and royal fern (Osmunda japonica) [6,17]. As these ferns can propagate clonally, large amounts of their sprouts or fiddleheads are harvested for foodstuffs in Japan. Although these species are common, sustainable harvesting is still an important issue because harvesting activities are generally allowed in a limited area near each settlement, with the areas serving as common-pool resources for local residents [14]. Given that these ferns have been harvested by local people for a long period of time, local habitats and harvesting sites are likely influenced by both natural and anthropogenic factors. By analyzing the spatial dependencies of each fern species harvest, 
it should be possible to show how local people harvest differently by paying attention to important habitat conditions for each species.

The objective of this study was to analyze the factors affecting differences in the spatial patterns of harvesting among the three fern species due to the importance for maintaining effective and sustainable harvesting. We hypothesized that the spatial characteristics of harvesting sites are affected by both natural (e.g., terrain features) and anthropogenic (e.g., land use/management and distance to roads) factors depending on the fern species.

\section{Data and Methods}

\subsection{Study Area}

This study was conducted in an area where the harvesting of edible wild plants has a long tradition and is still common. The location is in Tadami Town in the western Fukushima Prefecture of Northeastern Japan, where forest covers more than $90 \%$ of the land (Figure 1). This area extends $56 \mathrm{~km}^{2}$ (approximately $37^{\circ} 17^{\prime}-37^{\circ} 22^{\prime} \mathrm{N}, 139^{\circ} 28^{\prime}-139^{\circ} 34^{\prime}$ E) including two villages (107 households in total) located along the main valley floor. The elevation ranges from 460 to $960 \mathrm{~m}$ a.s.1. The area is in a cool-temperate region, where there is snow cover from November to early May, with a maximum snow depth of 2 to $4 \mathrm{~m}$. Due to the heavy snowfall during a single winter season reaching 10 to $15 \mathrm{~m}$ in depth, this area has an unusual mosaic of forests and scrublands $[18,19]$. Old-growth beech (Fagus crenata) forests dominate on the slopes, whereas snow avalanche scrubs (e.g., Quercus crispula, Clethra barbinervis etc.) are distributed on the steep slopes. Coppice oak forests (e.g., Quercus crispula and Quercus serrata) and conifer plantation forests, mainly Japanese cedar (Cryptomeria japonica) with some larch (Larix kaempferi) plantations, are found near roads and settlements. Five-needle pine (Pinus parviflora) forests are located on steep ridges. Few young broadleaf forests $<10$ years due to the small-scale clear cutting were also patchily distributed. On the forest floor, abundance and composition of herb layer was variable according to the forest type and structure. Dwarf bamboo (Sasa palmata, S. nipponica) was dominant in some parts of this area. Residents in the villages harvest various edible plants in the wild after the snowmelt at the end of April until mid-July. Outsiders are permitted to harvest if a daily entrance fee is paid.

\subsection{Target Fern Species}

We analyzed the harvesting sites of the three ferns, all of which are summer-green ferns native to Japan [20,21]. Ostrich fern is widely distributed in cool-temperate regions [20], particularly in areas with rich and moist soils on fluvial deposits [22]. Its fiddlehead has been consumed as a popular wild vegetable in North America and Northern Japan [23]. Bracken is distributed worldwide and has become dominant in some grasslands [24,25]. Although it has deleterious effects on human health [26,27], its first sprout is an important food item in East Asia [28-30], because its carcinogenic contents can be largely removed by boiling the harvested sprouts in water with wood ash or sodium bicarbonate [31]. Japanese royal fern (Osmunda japonica) is distributed in East Asia and has biological similarity to royal fern (Osmunda regalis) that is distributed worldwide [32]. The first sprouting of this fern has been commonly used as a sun-dried preserved vegetable in Japan [14]. 
Figure 1. Study area.

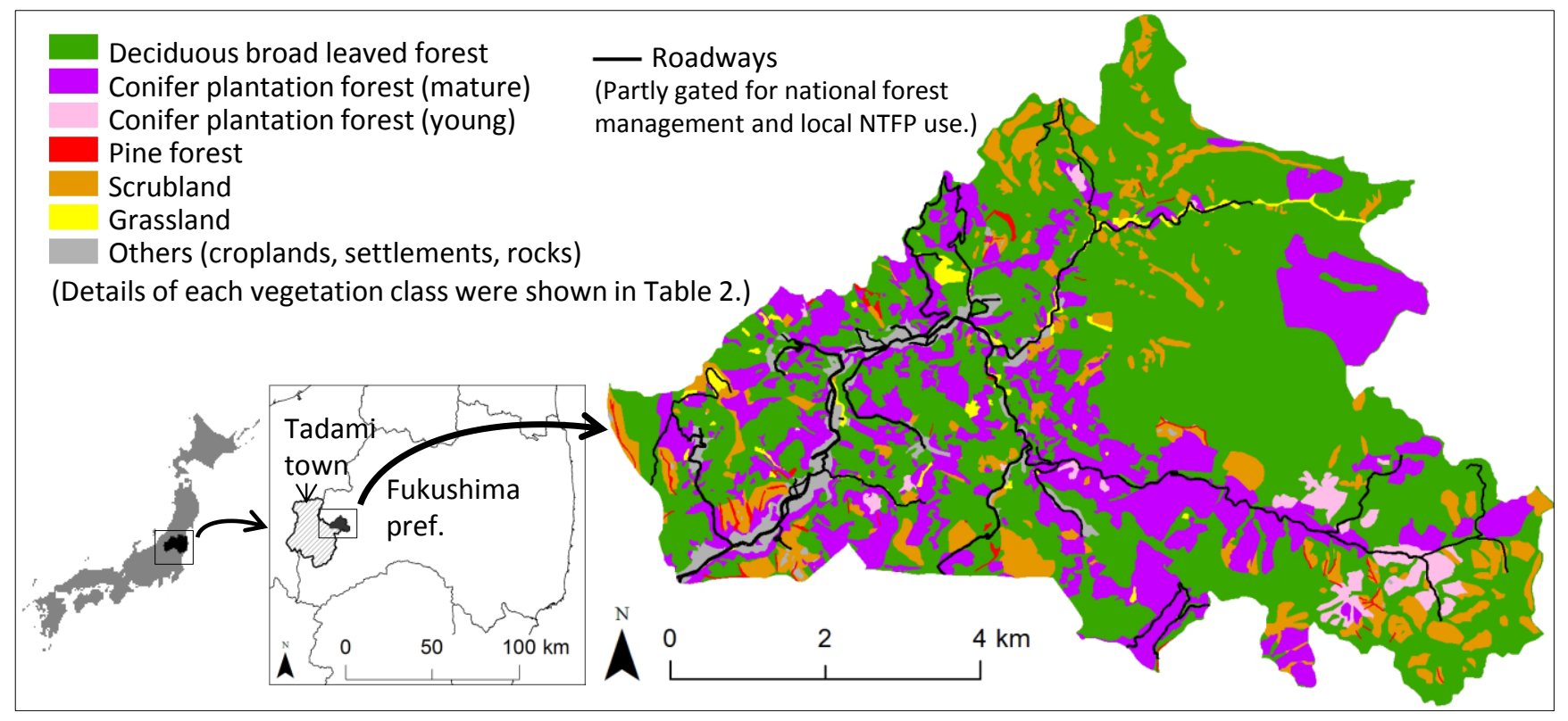

\subsection{Harvesting/Non-Harvesting Sites}

To distinguish the areas where dwellers actually harvest each fern species for construction and verification of the model, we distributed small GPS devices (igot-U GT-120, Mobile Action Technology, Inc., Taiwan), which weigh $20 \mathrm{~g}$ each and could be stored in a cap, to five experienced harvesters (male, age 65-78 at the time) and asked them to record their daily activities whenever they went to harvest in the wild. All of them were pensioners from different households and were selected as respondents because they had a long experience of harvesting wild plants from their childhood. The start and finish time of harvesting as well as names of harvested or targeted species were recorded to elucidate the GPS tracks of harvesting. This survey was conducted from May to July 2009, which is the harvest season in this area. A threshold velocity of $4 \mathrm{~km} / \mathrm{h}$ between each pair of GPS track points recorded every 15 seconds was used to remove tracks that involved access by car. To delineate harvesting sites as polygons, a Gaussian kernel density function with a fixed radius of $20 \mathrm{~m}$ was applied to the GPS point clouds, and the polygons with $95 \%$ kernel density were delineated as harvesting sites using the Geospatial Modeling Environment (GME ver. 0.7.2 RC2) [33]. Here, we excluded any GPS points that were located away from the others that could be identified as a cloud. Based on interviews with the harvesters, nine harvesting-site polygons, i.e., 6, 2, and 1 sites for ostrich fern, bracken, and royal fern, respectively, were additionally digitized. All the harvesting sites were confirmed at least once in the field by the authors. Absence data, i.e., non-harvest sites, were identified as the rest of the study area excluding the harvesting sites and their surroundings within a radius of $100 \mathrm{~m}$ so as not to be confused with the harvest sites.

Stratified random sampling [34] was used to obtain an equal number of harvesting/non-harvesting samples (i.e., 300 samples each) for each fern species. Half of the samples were used for training of the GLM, and the other half for verification. We conducted this sampling five times and divided each sample in half. In this way, a total of 10 sets of samples were prepared and tested for each fern species to obtain robust verification results. 


\subsection{GIS Data Set}

The GIS data set used for describing the spatial characteristics of harvesting sites of ferns is summarized in Table 1. These spatial characteristics were categorized into three groups of factors: vegetation, terrain features, and proximity to roads. We selected these factors based on field observations, interviews with harvesters, and previous descriptions of harvesting sites of these ferns [35]. Part of these factors have also been used in other studies by the authors [6]. Terrain features were mainly used for describing natural environmental factors, whereas proximity to roads was used to represent anthropogenic factors. Vegetation classes were mainly used for describing natural environmental factors, except classes of conifer plantations and some grasslands and scrublands that had been logged or clear cut by humans.

Table 1. Explanatory variables.

\begin{tabular}{|c|c|c|c|c|c|c|}
\hline $\begin{array}{c}\text { Explanatory } \\
\text { variables }\end{array}$ & Description & Min & $\operatorname{Max}$ & Mean & $\begin{array}{l}\text { Std. } \\
\text { Dev. }\end{array}$ & Unit \\
\hline Vegetation $^{1}$ & $\begin{array}{l}\text { Vegetation classes, i.e., deciduous } \\
\text { broadleaved forest, young and mature } \\
\text { conifer plantations, pine forest, } \\
\text { scrubland and grassland. }\end{array}$ & & & & & - \\
\hline
\end{tabular}

Terrain features derived from a 20-m digital elevation model

(DEM)

\begin{tabular}{|c|c|c|c|c|c|c|}
\hline Gradient $^{2}$ & $\begin{array}{l}\text { The maximum rate of elevation change } \\
\text { between each cell and its neighbors. }\end{array}$ & 0.06 & 54.68 & 21.41 & 8.63 & degree \\
\hline Aspect $^{3}$ & $\begin{array}{l}\text { Cosine transformation of aspect } \\
\text { (clockwise from north) to } 16 \text { directions: } \\
\cos [(\text { aspect }+n \times 22.5) / 180 \times \pi] \\
n=0,1, \ldots 7 \text {. }\end{array}$ & -1 & 1 & -0.050 & 0.714 & - \\
\hline $\begin{array}{l}\text { Relative slope } \\
\text { position } 4\end{array}$ & $\begin{array}{l}\text { The relative height from the nearest } \\
\text { drainage to each grid point divided by } \\
\text { the vertical size of a sideslope. }\end{array}$ & 0 & 1 & 0.63 & 0.33 & - \\
\hline $\begin{array}{l}\text { Potential solar } \\
\text { radiation }^{2}\end{array}$ & $\begin{array}{l}\text { Potential solar radiation with } \\
\text { monthly interval. }\end{array}$ & 45,0348 & 156,7600 & 126,3764 & 17,4382 & $\mathrm{WH} / \mathrm{m}^{2}$ \\
\hline $\begin{array}{l}\text { Topographic } \\
\text { wetness index } \\
(\mathrm{TWI})^{5}\end{array}$ & $\begin{array}{l}T W I=\ln (A / \tan B), \text { where } A \text { is } \\
\text { specific catchment area while } B \text { is } \\
\text { slope gradient. }\end{array}$ & 9.07 & 27.31 & 11.56 & 1.90 & - \\
\hline $\begin{array}{l}\text { Proximity to } \\
\text { roads }\end{array}$ & $\begin{array}{l}\text { Path distance to the nearest roads } \\
\text { weighted by the slope gradient. }\end{array}$ & 0 & 2538.6 & 652.3 & 542.4 & $\mathrm{~m}$ \\
\hline
\end{tabular}

${ }^{1}$ Details of each class are shown in Table $2 ;{ }^{2}$ ArcGIS Spatial Analyst was used; ${ }^{3}$ We used the cosine transformation to deal with the circular nature of the aspect data [36]; Statistics of min, max etc. were for the cosine transformation of aspect to the north; ${ }^{4}$ Height from the nearest drainage was measured similarly to the algorithm of Rennó et al. (2008) [37]; ${ }^{5}$ Direction infinity (D-infinity) flow-routing algorithm [38] was used for computing the specific catchment area.

We digitized a 1:25,000 physiognomic vegetation map made by interpreting aerial photographs taken between 1978 and 1980, supplemented with ancillary fieldwork by the Board of Education in 
Tadami town [39]. We significantly updated this map, especially the clear-cut or afforested areas (by Japanese cedar with some larch plantations) by interpreting ortho-rectified aerial photos taken in 2004 and 2009 and 1:50,000 forest planning maps published by the Forestry Agency and Fukushima Prefecture in 2006. Conifer plantation forest was classified as young or as mature at 20 years after planting because canopy openings with brighter light conditions in the understory still dominate until around this age due mainly to heavy snow conditions. The polygon map was further converted into a 20-m grid raster. The six dominant vegetation classes used in this study were deciduous broadleaved forest, mature conifer plantation, young conifer plantation, pine forest, scrubland, and grassland (see Figure 1 and Table 2). Terrain features such as gradient, aspect, relative slope position, topographic wetness index (TWI), and potential solar radiation were generated from a 20 -m digital elevation model (DEM) that was interpolated from the 10-m interval contours of 1:25,000 topographic maps published by the Geospatial Information Authority of Japan. The proximity to forestry paths or roadways accessible by car was computed using path distance, i.e., the shortest distance on the surface. To describe the difficulty accessing steeper slopes, a symmetric inverse linear function with a maximum absolute gradient of 60 degrees was used based on ArcGIS 10.1 Spatial Analyst extension.

Table 2. Vegetation classes and dominant tree species in the study area.

\begin{tabular}{|c|c|c|c|c|}
\hline No. & Vegetation class $^{1}$ & Subclass & Dominant tree species $^{2}$ & Area (\%) \\
\hline \multirow[t]{3}{*}{1} & Deciduous broadleaved forest & Japanese beech forest & Fagus crenata & 58.4 \\
\hline & & Coppice forest & $\begin{array}{l}\text { Quercus crispula, } \\
\text { Quercus serrata }\end{array}$ & \\
\hline & & Riparian forest & $\begin{array}{l}\text { Pterocarya rhoifolia, } \\
\text { Salix dolichostyla }\end{array}$ & \\
\hline 2 & Conifer plantation (mature) & $\begin{array}{c}\text { Japanese cedar/larch plantation } \\
\text { (age }>=20 \text { years) with } \\
\text { closed canopies }\end{array}$ & $\begin{array}{l}\text { Cryptomeria japonica, } \\
\text { Larix kaempferi }\end{array}$ & 24.5 \\
\hline 3 & Conifer plantation (young) & $\begin{array}{c}\text { Japanese cedar/larch plantation } \\
\text { (age }<20 \text { years) with dominant } \\
\text { canopy openings }\end{array}$ & $\begin{array}{l}\text { Cryptomeria japonica, } \\
\text { Larix kaempferi }\end{array}$ & 2.2 \\
\hline 4 & Pine forest & $\begin{array}{l}\text { Japanese white/red pine forest } \\
\text { mainly located on sharp ridges }\end{array}$ & $\begin{array}{c}\text { Pinus parviflora var. } \\
\text { pentaphylla, } \\
\text { Pinus densiflora }\end{array}$ & 0.7 \\
\hline \multirow{3}{*}{5} & & & Quercus crispula, & \\
\hline & Scrubland & Snow avalanche scrubland & $\begin{array}{l}\text { Weigela hortensis, } \\
\text { Clethra barbinervis }\end{array}$ & 9.8 \\
\hline & & Scrubland after clear cut & $\begin{array}{l}\text { Fagus crenata, Quercus } \\
\text { crispula, Quercus serrata }\end{array}$ & \\
\hline 6 & Grassland & $\begin{array}{l}\text { Seminatural grassland, Riparian } \\
\text { grassland and marsh }\end{array}$ & - & 1.3 \\
\hline 7 & Others & $\begin{array}{l}\text { Settlement, bareland, rock, rice } \\
\text { paddy, cropland, or waterbody }\end{array}$ & - & 3.2 \\
\hline
\end{tabular}

\footnotetext{
${ }^{1}$ Six dominant vegetation classes (1-6) were used for the analysis due to the difficulty in separating subclasses observed in the field from air photo interpretation; ${ }^{2}$ Based on Kawabata (2001) [39].
} 


\subsection{Generalized Linear Model}

To analyze the spatial characteristics of harvesting sites of ferns, we used a generalized linear model (GLM) with binomial distribution and logit link function, i.e., binomial logistic regression, one of the most commonly used models in habitat suitability mapping based on presence/absence data [7,9]. Presence/absence of harvesting sites of edible ferns was used as the response variable, whereas a variety of environmental or geospatial factors that may have some relation to the selection of harvesting sites, e.g., vegetation, terrain features, and accessibility from roadways (see Table 1), were used as explanatory variables. First, univariate GLM for each explanatory variable was employed to identify the statistically significant variables for the harvesting/non-harvesting sites of each fern species. Multivariate GLM was then used with the variables that were statistically significant $(p<0.0001)$ in the univariate GLM. If any two variables were correlated, i.e., the absolute value of the Pearson's correlation coefficient was over 0.7, the explanatory variable with lower Akaike information criterion (AIC) value was chosen. Variance inflation factor (VIF) was also computed for each variable to avoid multicollinearity. Using backward stepwise variable selection, the model with the smallest AIC value was selected for each fern species. While there is debate over the validity of stepwise variable selection compare to others such as multi-model inference approach [40], similar predictive ability can often be obtained from each approach [41]. Variables whose effects changed from positive to negative or vice versa between the univariate and multivariate GLMs were also excluded from the multivariate GLMs. We used the statistical software package R (version 2.15.0; R Development Core Team) for these analyses.

\subsection{Model Verification}

Based on the results of the GLM, potential harvesting sites of each fern species were estimated within the study area. Note that "potential harvesting sites" should be interpreted as sites that are suitable both for their habitat and for harvesting in terms of their human accessibility. Estimated and actual distribution of harvesting sites of each fern species were then compared for verification. We computed the area under the receiver operating characteristic (ROC) curve (AUC), which provided a single measure of overall accuracy, ranging from 0.5 to 1.0 , that was independent from a particular threshold value $[42,43]$. The kappa index was also generated from the ROC curve using a cutoff value such that the kappa value was maximized [44].

\subsection{Comparison of the Potential Harvesting Sites among the Three Fern Species}

We further analyzed the relationship between each explanatory variable and the estimated potential distribution of ferns by computing the area ratio of the estimated presence pixels, i.e., the probability of presence was over 0.5 , for each class of explanatory variable. We used this cutoff value because the kappa became maximized around this value (i.e., $0.48 \pm 0.05$, mean $\pm \mathrm{SD}$ ). Explanatory variables with continuous values, e.g., terrain features and accessibility from roads, were classified into 8-16 classes in this analysis. 


\section{Results}

\subsection{Comparison of the Potential Harvesting Sites among the Three Fern Species}

In total, 53 person-days of GPS tracks for harvesting edible wild plants were obtained from May to July 2009. Among these, 46 person-days of tracks (87\%) included harvest of the three targeted fern species: 10, 22, and 14 person-days for harvesting ostrich fern, bracken, and royal fern, respectively. Additionally, seven sites (three and four sites for bracken and royal fern, respectively) were appended based on the additional GPS survey in 2010. Harvest season differed among the three fern species. Ostrich fern was harvested mainly from early to mid-May after snowmelt. Gatherers then started harvesting royal fern, continuing from mid-May until early June. Bracken harvest started in June and continued until early July. We found that each fern species was harvested independently in different sites and seasons.

The results of multivariate GLM using all samples for each fern species are shown in Table 3. Variables that were correlated with each other at an absolute Pearson's correlation value $>0.7$ were topographic wetness index (TWI) and relative slope position. Between these, slope position was always selected as the variable with the smallest AIC value for each fern species. VIF for each variable was always less than 2.0, indicating that multicollinearity effects were small.

For the harvesting sites of ostrich fern, grassland and "cosine transformation of slope aspect to the east" were positive predictors, whereas scrubland, slope position, and proximity to roadways were negative indicators. These results indicate that ostrich fern is likely to be harvested in the vicinity of roadways, in grasslands located in the valley floor or footslopes facing east.

For harvesting bracken, grassland was the most preferred land-cover type, followed by young conifer plantation, scrubland, and mature conifer plantation. Potential solar radiation and "cosine transformation of slope aspect to the northeast" were positive indicators, whereas proximity to roadways responded negatively. These results indicate that bracken tended to be harvested near roadways on the sunny side of slopes but likely facing to the northeast. Often the area was covered by grassland or young conifer plantation, and sometimes, it was covered by scrubland or mature conifer plantation.

Scrubland and "cosine transformation of slope aspect to the southeast" were strong positive predictors of the royal fern harvesting sites. Both the potential solar radiation and slope position were negative indicators. Differing from the other two fern species, proximity to roadways was not selected as a significant variable for this fern. These results indicate that royal fern is likely to be harvested in the scrublands in the relatively low part of shaded slopes, often facing to the southeast.

Verification results of GLM are summarized in Figure 2. Among the three fern species, estimation accuracy for bracken was consistently the highest, followed by ostrich fern and royal fern. AUC values for ostrich fern and royal fern can be considered reasonable discriminations, whereas good discrimination for bracken [45]. For kappa statistic, moderate levels of accuracy were obtained for ostrich fern and royal fern, while a substantial level of accuracy was obtained for bracken [43]. 
Table 3. Results of generalized linear models (GLMs).

\begin{tabular}{|c|c|c|c|c|}
\hline \multirow[t]{2}{*}{ Selected variable ${ }^{1}$} & \multicolumn{2}{|c|}{ Coefficient } & \multirow{2}{*}{$z$ value } & \multirow{2}{*}{ Odds ratio $^{2}$} \\
\hline & Mean & Std. Err. & & \\
\hline \multicolumn{5}{|l|}{ Ostrich fern } \\
\hline Intercept & 2.0149 & 0.0645 & 31.224 & - \\
\hline Grassland & 2.5130 & 0.2091 & 12.016 & 12.34 \\
\hline Scrubland & -1.4180 & 0.1495 & -9.484 & 0.24 \\
\hline Slope position & -2.2410 & 0.0992 & -22.589 & 0.11 \\
\hline $\cos \left(\text { aspect }_{E}\right)^{3}$ & 0.6971 & 0.0478 & 14.597 & 2.01 \\
\hline Proximity to roads & -0.0025 & 0.0001 & -22.807 & 0.08 \\
\hline \multicolumn{5}{|l|}{ Bracken } \\
\hline Intercept & -11.8500 & 0.5745 & -20.62 & - \\
\hline Grassland & 4.9820 & 0.2402 & 20.74 & 145.77 \\
\hline Scrubland & 1.7040 & 0.1448 & 11.77 & 5.50 \\
\hline Mature conifer plantation & 1.1840 & 0.1028 & 11.52 & 3.27 \\
\hline Young conifer plantation & 3.5000 & 0.1905 & 18.37 & 33.12 \\
\hline Potential solar radiation & $8.65 \times 10^{-6}$ & $4.32 \times 10^{-7}$ & 20.03 & 2.37 \\
\hline $\cos \left(\operatorname{aspect}_{\mathrm{NE}}\right)^{3}$ & 2.8490 & 0.1028 & 27.71 & 17.27 \\
\hline Proximity to roads & -0.0041 & 0.0002 & -21.2 & 0.02 \\
\hline \multicolumn{5}{|l|}{ Royal fern } \\
\hline Intercept & 8.6190 & 0.2796 & 30.83 & - \\
\hline Scrubland & 1.2400 & 0.0834 & 14.86 & 3.46 \\
\hline Potential solar radiation & $-6.72 \times 10^{-6}$ & $2.23 \times 10^{-7}$ & -30.2 & 0.51 \\
\hline Slope position & -1.4970 & 0.0887 & -16.87 & 0.22 \\
\hline $\cos \left(\text { aspect }_{\mathrm{SE}}\right)^{3}$ & 1.3150 & 0.0571 & 23.05 & 3.72 \\
\hline
\end{tabular}

${ }^{1}$ Variables that were statistically significant $(p<0.0001)$ in the multivariate GLM for each fern species are shown in this table; ${ }^{2}$ Odds ratio $=\exp ($ coefficient $)$; To compute the odds ratios of solar radiation and path distance, their coefficients were multiplied by 100,000 and 1000 , respectively to show the clear effects of these parameters; ${ }^{3} \cos \left(\right.$ aspect $\left.t_{\mathrm{E}}\right)$ indicates "cosine transformation of slope aspect to the east"; E, east; NE, northeast; SE, southeast.

Figure 2. Model accuracy measured by (A) the area under the receiver operating characteristic (ROC) curve (AUC) and (B) kappa.

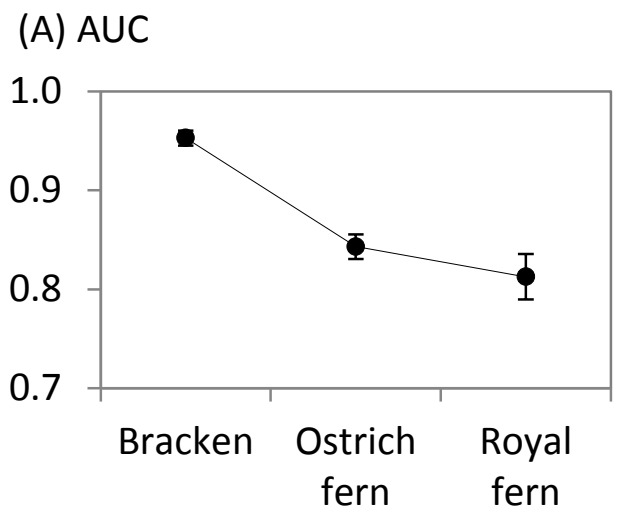

(B) Kappa

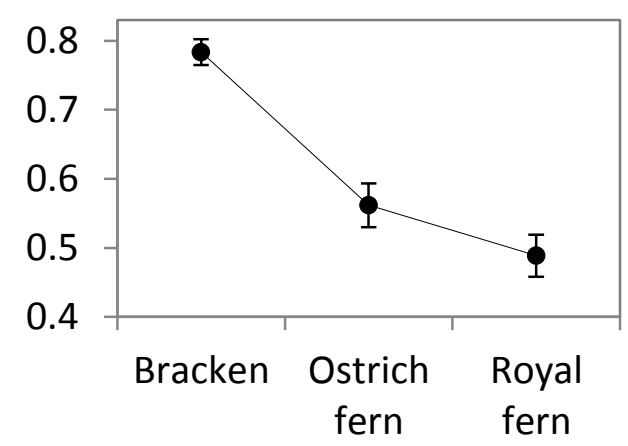

- Error bar shows standard deviation ( $n=10$ for each species). 


\subsection{Estimated Potential Harvest Sites and their Differences among Ferns}

The estimated potential harvesting sites differed among the three fern species (Figure 3). Potential harvesting sites of ostrich fern were mainly located along valley floors and lower slopes near roadways (see Figure 3A). For bracken, potential harvest sites were limited mainly to sunny grasslands, young conifer plantations, and scrublands nearby roadways (see Figure 3B). Potential harvest sites of royal fern were mostly located on the shaded side of slopes, mainly facing to east, where snow avalanche scrublands dominate (see Figure 3C). Some harvest sites of royal fern were even located far from roadways, showing a difference between royal fern and the two other species.

Figure 3. Estimated potential harvesting sites of three edible wild ferns (i.e., A, Ostrich fern; B, Bracken; C, Royal fern) based on the results of generalized liner models (GLMs).

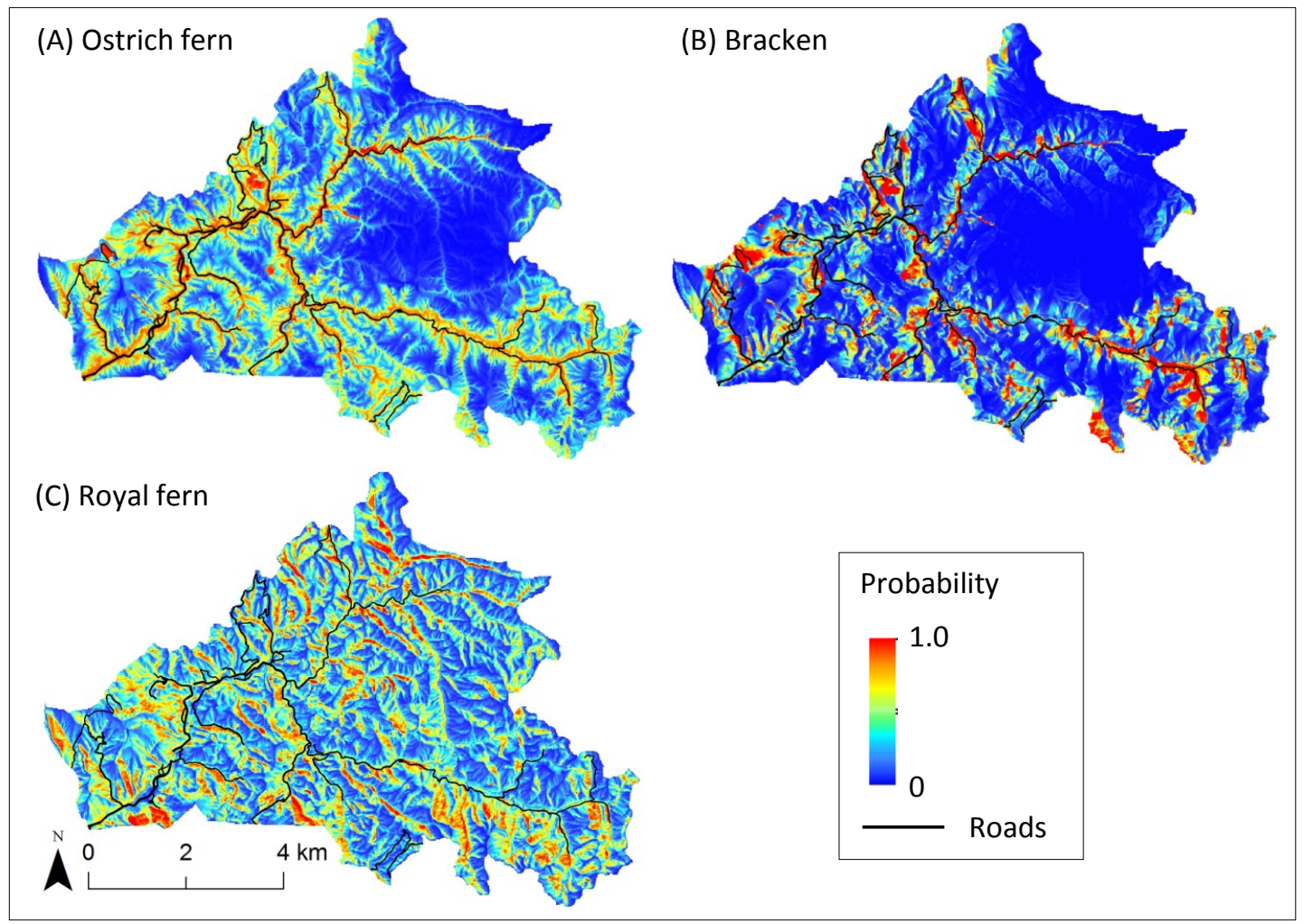

Comparing the spatial distribution of estimated potential harvesting sites in terms of each explanatory variable, clear differences were observed among the three fern species (Figure 4). Strong preference of grassland was found for ostrich fern and bracken, whereas scrubland was strongly preferred by royal fern (see Figure 4A). Although gradient was only selected as a significant variable in the univariate GLM and not selected in the multivariate GLM for each fern species; a strong preference for steeper slopes was found in royal fern, whereas gentler slopes were preferred by ostrich fern and bracken (see Figure 4B). A clear preference for northeast- or east-facing slopes was observed for all three fern species, particularly for royal fern and bracken (see Figure 4C). The slope aspect preference differed in part from the results of multivariate GLM (see Table 3) due mainly to the balancing of variables with potential solar radiation. The lower sides of slopes were strongly preferred by ostrich fern and royal fern, whereas no clear preference with respect to slope position was found for bracken (see Figure 4D). Shaded side slopes were strongly preferred by royal fern, whereas relatively 
sunny sides of slopes were preferred by bracken and slightly preferred by ostrich fern (see Figure 4E). A humid environment was preferred by ostrich fern, but not clearly so for bracken and royal fern (see Figure 4F). Potential harvesting sites of ostrich fern and bracken were mainly limited to locations near roadways, i.e., less than about $500 \mathrm{~m}$, whereas royal fern was harvested even far away from roadways (see Figure 4G).

Figure 4. Relations between explanatory variables ( $x$-axis) and the area ratio of the estimated presence pixels in each class ( $y$-axis). Explanatory variables are (A) vegetation; (B) gradient, $(\mathbf{C})$ aspect, $(\mathbf{D})$ relative slope position, $(\mathbf{E})$ area solar radiation, $(\mathbf{F})$ topographic wetness index (TWI), and (G) path distance weighted by slope gradient.

(A) Vegetation

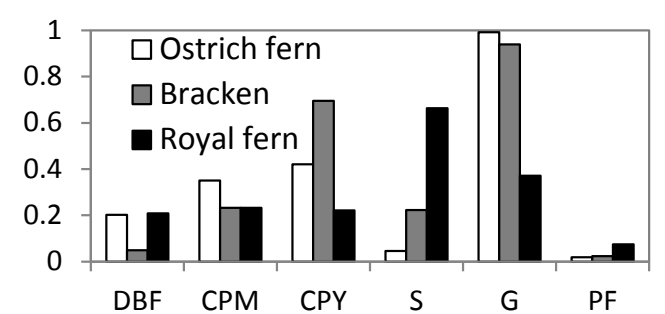

(DBF, deciduous broadleaved forest; CFY, conifer plantation young; CFM, conifer plantation mature; $S$, scrubland; G, grassland; PF, pine forest)

(C) Aspect

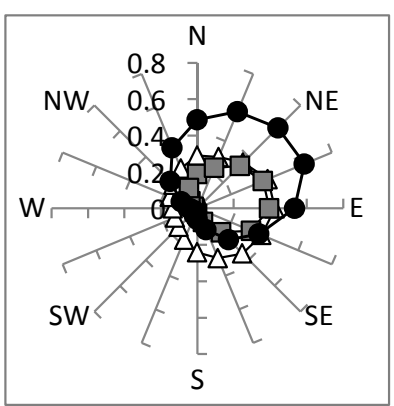

(N, north; E, east; S, south; W, west)

(E) Area solar radiation

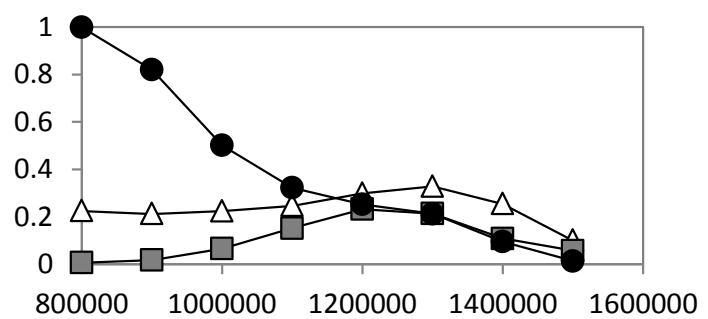

$\left(\mathrm{WH} / \mathrm{m}^{2}\right)$

(G) Path distance weighted by slope gradient

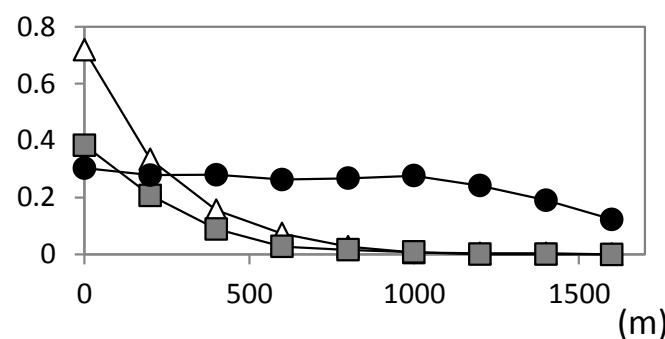

(B) Gradient

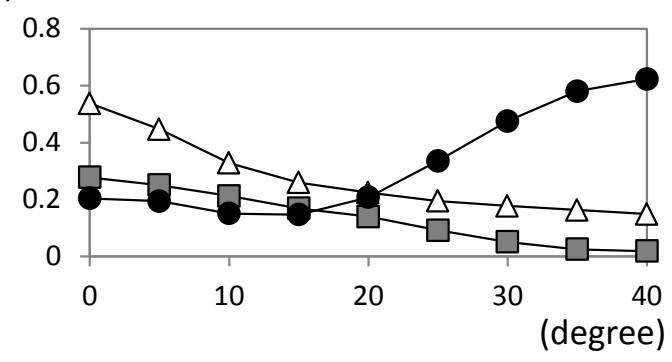

(D) Relative slope position

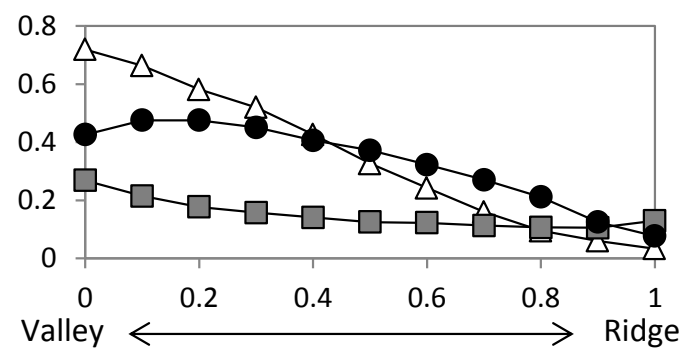

(F) Topographic wetness index (TWI)
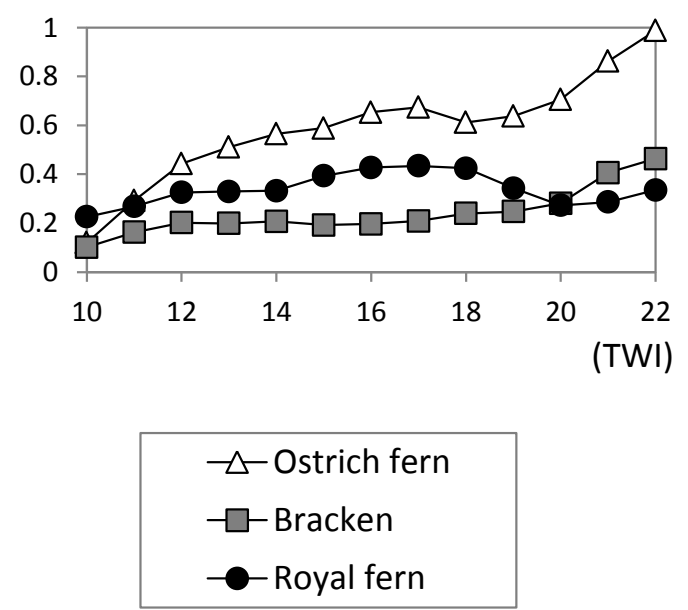

- Several classes in the lower and upper parts of (B) and (F) and upper parts of (E) were grouped into the lowest or highest classes on the $x$-axis.

- Radar chart was used for (C) Aspect. 


\section{Discussion}

Harvesting sites of the three ferns show a common bias toward relatively disturbed habitats such as canopy openings, grasslands, or scrublands, but individual species showed distinctively different spatial distribution according to their habitat preference. Such habitat was preferred as the harvesting sites mainly because the population density and size of the individual ferns tended to be larger in these areas than they are in the understory of stable mature beech or coppice forests shaded by forest canopies [22,46,47].

Ostrich fern preferred canopy openings along riparian areas, where exposed habitat with humid conditions is maintained by riparian disturbances such as sediment movement along valley floors and alluvial cones [48,49], with rich and moist soils often on fluvial deposits [22]. Abandoned rice paddies or croplands along streams or foot slopes were also used for harvesting this fern, as these locations also have humid and exposed conditions with rich soils.

Bracken shows a preferences for human-disturbed grassland, scrubland, and young conifer plantations, which largely corresponds with previous field observations of this fern [24,50-52], although these studies concentrated only on habitat distribution of this fern and not on harvesting sites. Although we did not analyze in detail the land-use history of the areas studied, this history has also indirectly affected the formation of harvesting sites of bracken, as some of the conifer plantations close to settlements were formerly used as slash-and-burn farmlands or hayfields for green manure and/or thatching roof grass until the 1960s [53].

Different from bracken, the shaded lower sides of mainly north- to east-facing slopes, often covered by scrubland, were preferred as royal fern harvesting sites. This slope aspect is the leeward side of the strong winter monsoon from the Sea of Japan, with heavy snowfall and scrublands naturally maintained by frequent avalanches in the snowmelt season [54-56]. Lower parts of such slopes are suitable for royal fern growth because humid environments with rich soil are annually maintained during the snowmelt season [39].

Although accessibility from roadways is likely to be important for harvesting, it was not selected as an important factor for royal fern. This is due mainly to the differences in the spatial distribution of suitable harvesting sites among the fern species in terms of the accessibility. Snow avalanche scrublands for harvesting royal fern are found at a wide range of distances from roadways, whereas riparian grasslands for harvesting ostrich fern are mostly near roads because road networks are likely to be located along valley floors to avoid steeper slopes. Additionally, exposed landscapes of anthropogenic origin, e.g., grasslands developed in clear cuts or young conifer plantations, which are suitable harvest sites for bracken, were likely to be located near roads. Nevertheless, accessibility from roadways may also have importance even for harvesting royal fern. Potential harvesting sites of royal fern in more remote mountain areas are far from roadways in the villages in the western part of Tadami Town, where local people once harvested royal ferns by building temporary huts near harvesting areas until the 1980s, as royal fern harvesting was a main source of income [14].

Harvesting sites of the three wild ferns were influenced by both natural and anthropogenic factors. The most important natural factors were two types of disturbances, i.e., snow avalanches and riparian disturbances, both of which generally control the site conditions and vegetation mosaic in snowy mountains [56]. Avalanches are important for the land cover in our study area, as the area receives 
heavy snowfall in winter. Due to the frequent avalanches, natural scrublands are maintained and have been used as the ideal habitats and harvesting sites for royal fern [14]. For this reason, snowy mountains around the study area have been known as one of the largest production areas for harvesting naturally grown royal ferns in Japan [57]. Canopy openings along mountain streams have been known to be the ideal harvesting sites of various herbal species including ferns [12,16], although there are likely some differences among species due to microtopographic conditions.

Anthropogenic factors such as land use/management (e.g., logging and mowing) and accessibility from roadways also have great importance for harvesting ferns. We found that the human disturbances of small-scale agriculture and forestry, including the abandoned areas, often had positive effects on harvesting edible ferns because these ferns prefer exposed landscapes. Because the preferred landscape differs among fern species, the type and intensity of disturbance is also critical. A variety of exposed landscapes including grassland and scrubland dominated in rural mountainous villages in Japan until the 1960s, as many people were still dependent on local organic materials such as charcoals and fertilizers $[58,59]$. This indicates that such landscapes likely also provided important harvesting sites of edible herbs including ferns at that time. As land cover mosaics have largely changed due to changes in lifestyle in the past half century [60], there are likely some differences between present and past harvesting sites of ferns. Decreases in young conifer plantations due to the decline in forestry activities, which has been documented in other areas in Japan [61], would also have affected the decreases in harvesting sites, particularly for bracken. For these reasons, as well as the influence of the energy revolution in the 1960s, current harvesting sites may be smaller than historic sites.

Another important anthropogenic factor, namely the accessibility of harvest sites from roadways, had differing effects on harvesting intensity at each site. As each fern habitat includes not only accessible sites but also sites far from roadways, fern populations are not likely to be extinguished. Nevertheless, it is still important to maintain the accessible sites for assuring annual harvesting because edible ferns are common-pool resources to be harvested every year for local dwellers in each village $[6,14]$. In this respect, local harvesters generally leave part of the first sprouting or fiddleheads in each fern crown to ensure the sustainability of the harvesting sites. Although we do not have sufficient data to fully evaluate this issue, we surmise that accessibility may also have negative effects on harvesting sites because sites nearby roadways are more likely to be overharvested [62], particularly by outsiders, who are generally less attentive to sustainability issues.

Our results can be further interpreted to estimate the effects of changes in these factors, particularly anthropogenic factors that can be altered relatively in a short period. For example, if exposed landscapes such as grasslands and young conifer plantations increase, the potential harvest sites of bracken will become larger. Construction of roads also would have positive effects on increasing accessible harvest sites of ostrich fern and bracken, whereas the area will be smaller if some road sections were abandoned. As harvesting activities have been continuously changing due to changes in land use/management, aging, and depopulation [16], such further scenario-based prediction based on the results of the GLM would be useful for estimating changes in the provisioning services of edible wild ferns. Our results evaluated the state of edible fern harvest just before the accident at the Fukushima Daiichi Nuclear Power Plant on March 2011; further analysis of direct/indirect effects of that accident will also be important. 
This study used GPS tracks for analyzing the spatial characteristics of harvesting sites of edible fern species. GPS tracks have sometimes been used as a participatory mapping tool, e.g., demarcation of village boundaries by local inhabitants [63]; however, few studies have analyzed spatial characteristics of NTFP harvest sites by distributing multiple GPS devices to harvesters and having them record their activities. After collecting the spatial distribution of harvesting sites, it is simple to analyze their spatial characteristics using GIS and statistical models. The results can be used as base maps and models for estimating the spatial distribution of edible wild ferns for effective and sustainable harvesting. Additionally, temporal characteristics of individual GPS tracks can be further investigated by such methods as time-geographic analysis, which can elucidate spatiotemporal characteristics of the individual person-trips of local harvesters [11], though that type of analysis is beyond the scope of this study. Since a great number of people living near forests have long been dependent on the provisioning services of various NTFP species [1,3], our use of GPS and statistical models would be applicable for evaluating harvesting of various NTFP species in other regions around the world.

\section{Conclusions}

This study analyzed the spatial characteristics of harvesting sites of three edible wild ferns that were obtained by GPS tracking and harvesters' daily records. We found clear differences in spatial characteristics of harvesting sites among fern species. Each fern species is harvested under specific land conditions and under different disturbance regimes such as riparian disturbances for ostrich fern, snow avalanches for royal fern, and anthropogenic disturbances, e.g., clear cutting and mowing, for bracken. Accessibility from roadways was also important for harvesting but showed differences due mainly to the different resource distributions among ferns. These results indicate the importance of a variety of both natural and anthropogenic factors for their harvest. Our results clearly showed that local inhabitants harvested different edible ferns by changing their harvest sites in the mosaic of vegetation in snowy mountainous settlements maintained by both natural (e.g., snow avalanches and riparian events) and anthropogenic (e.g., logging) factors. Statistical models and the estimated potential harvesting sites maps clearly show the spatial characteristics of harvesting sites. These results are useful for visualizing the spatial distribution of ecosystem provisioning services in mountainous settlements. Note that potential harvest sites do not indicate potential habitats of each species. Further study is required to shed light on the difference between habitats and harvest sites information that would be also important for maintaining a sustainable harvest of these species.

\section{Acknowledgments}

We wish to thank people in Tadami Town, particularly, Koukichi Kariya and Masanobu Saito, who accepted our GPS tracking survey and shared their knowledge about harvesting edible wild ferns, and Isamu Nikkuni, who provided us with the original vegetation maps. Researchers from the FFPRI supported our field survey. Kaori Suzuki entered data from harvesters' daily records field notes. Our thanks also go to several fellow researchers for their constructive advice on the earlier draft of this

study, e.g., Guillermo M. Pastur, CADIC Argentina, Rajesh B. Thapa, JAXA, and Satoko Kawarasaki, FFPRI. This study was supported by the Global Environment Research Fund (E-0801) of the Ministry 
of the Environment, Japan, and by a JSPS Grant-in-Aid for Scientific Research (24310035) of The Ministry of Education, Culture, Sports, Science and Technology, Japan.

\section{Conflicts of Interest}

The authors declare no conflict of interest.

\section{References}

1. Delang, C.O. Not just minor forest products: The economic rationale for the consumption of wild food plants by subsistance farmers. Ecol. Econ. 2006, 59, 64-73.

2. Cocks, M.; López, C.; Dold, T. Cultural Importance of Non-Timber Forest Products: Opportunities They Pose for Bio-Cultural Diversity in Dynamic Society. In Non-Timber Forest Products in the Global Context, Tropical Forestry 7; Shackleton, S., Shackleton, C., Shanley, P., Eds.; Springer-Verlag: Heidelberg, Germany, 2011; pp. 107-128.

3. Shackleton, C.M.; Pandey, A.K. Positioning non-timber forest products on the development agenda. For. Policy Econ. 2013, 38, 1-7.

4. Ticktin, T.; Shackleton, C. Harvesting Non-Timber Forest Products Sustainably: Opportunities and Challenges. In Non-Timber Forest Products in the Global Context, Tropical Forestry 7; Shackleton, S., Shackleton, C., Shanley, P., Eds.; Springer-Verlag: Heidelberg, Germany, 2011; pp. 149-169.

5. Schreckenberg, K. Products of a managed landscape: Non-timber forest products in the parklands of the Bassila region, Benin. Glob. Ecol. Biogeogr. 2013, 8, 279-289.

6. Matsuura, T.; Sugimura, K.; Miyamoto, A.; Tanaka, N. Knowledge-based estimation of edible fern harvesting sites in mountainous communities of northeastern Japan. Sustainability 2014, 6, 175-192.

7. Austin, M.P. Spatial prediction of species distribution: An interface between ecological theory and statistical modelling. Ecol. Model. 2002, 157, 101-118.

8. Boyce, M.S.; Vernier, P.R.; Nielsen, S.E.; Schmiegelow, F.K.A. Evaluating resource selection functions. Ecol. Model. 2002, 157, 281-300.

9. Guisan, A.; Zimmermann, N.E. Predictive habitat distribution models in ecology. Ecol. Model. 2000, 135, 147-186.

10. Guisan, A.; Thuiller, W. Predicting species distribution: Offering more than simple habitat models. Ecol. Lett. 2005, 8, 993-1009.

11. Nishimura, Y.; OKamoto, K.; Somkhit, B. Time-geographic analysis on natural resource use in a village of the Vientiane Plain. Southeast Asian Stud. 2010, 47, 426-450.

12. Saito, H. Wild edible plant gathering activities practiced at ecotones (in Japanese with English abstract). Bull. Natl. Mus. Jpn. Hist. 2005, 123, 325-353.

13. Ikeya, K. Spatial structure of Zenmai gathering: A case study of the mountain village in the heavy snow zone. Sci. Rep. Tohoku Univ. Ser. Geogr. 1988, 38, 104-118.

14. Ikeya, K. Cultural ecology of Zenmai gathering in the northeastern Japan. Sci. Rep. Tohoku Univ. Ser. Geogr. 2004, 53, 1-28. 
15. Kawarasaki, H.S.; Sugimura, K. Estimation of frequency and locality of collection of wild mushroom and wild vegetables by internet search (in Japanese with English abstract). J. Jpn. For. Soc. 2012, 94, 95-99.

16. Matsuura, T.; Hayashi, M.; Sugimura, K.; Tanaka, N.; Miyamoto, A. Ecosystem services valuation of gathering edible wild plants/mushrooms - A case study in Tadami town, Fukushima prefecture (in Japanese with English abstract). Jpn. J. For. Plan. 2013, 47, 55-81.

17. Higa, M.; Nakao, K.; Tsuyama, I.; Nakazono, E.; Yasuda, M.; Matsui, T.; Tanaka, N. Indicator plant species selection for monitoring the impact of climate change based on prediction uncertainty. Ecol. Indic. 2013, 29, 307-315.

18. Kashimura, T. Ecological study of the natural forest vegetation in the snowy region along the lower Tadami valley. Ecol. Rev. 1968, 17, 153-170.

19. Kawano, S.; Nikkuni, I. Forest Vegetation, Flora and Fauna, and Biodiversity in Tadami-machi, Fukushima Prefecture, Honshu, Japan -Primaeval Beech and Riparian Forests, Sustainable Rich Flora and Fauna; Tadami-machi Board of Education: Tadami-machi, Japan, 2004; p. 23.

20. Iwatsuki, K. Ferns and Fern Allies of Japan (in Japanese with English Abstract); Heibonsha Ltd.: Tokyo, Japan, 1992; p. 311.

21. Sato, T. Phenology and wintering capacity of sporophytes and gametophytes of ferns native to northern Japan. Oecologia 1982, 55, 53-61.

22. Odland, A.; Naujalis, J.R.; Stapulionytè, A. Variation in the structure of Matteuccia struthiopteris populations in Lithuania. Biologija 2006, 1, 83-90.

23. Von Aderkas, P. Economic history of ostrich fern, Matteuccia struthiopteris, the edible fiddlehead. Econ. Bot. 1984, 38, 14-23.

24. Page, C.N. The taxonomy and phytogeography of bracken. Bot. J. Linn. Soc. 1976, 73, 1-34.

25. Pakeman, R.J.; Marrs, R.H. The conservation value of bracken, Pteridium aquilinum (L.) Kuhn, dominated communities in the UK, and an assessment of the ecological impact of bracken expansion or its removal. Biol. Conserv. 1992, 62, 101-114.

26. Wilson, D.; Donaldson, L.J.; Sepai, O. Should we be frightened of bracken? A review of the evidence. J. Epidemiol. Community Health 1998, 52, 812-817.

27. Gil da Costa, R.M.; Bastos, M.; Oliveira, P.A.; Lopes, C. Bracken-associated human and animal health hazards: Chemical, biological and pathological evidence. J. Hazard. Mater. 2012, 203-204, 1-12.

28. Hodge, W.H. Fern foods of Japan and the probrem of toxicity. Am. Fern J. 1973, 63, 77-80.

29. May, L.W. The economic uses and associated folklore of ferns and fern allies. Bot. Rev. 1978, 44, 491-528.

30. Pemberton, R.; Lee, N. Wild food plants in South Korea; market presence, new crops, and exports to the United States. Econ. Bot. 1996, 50, 57-70.

31. Hirono, I. Edible plants containing naturally occurring carcinogens in Japan. Jpn. J. Cancer Res. 1993, 84, 997-1006.

32. Kato, M. Distribution of Osmundaceae. Bull. Natl. Mus. Nat. Sci. Ser. B Bot. 2007, 33, 81-90.

33. Beyer, H.L. Geospatial Modelling Environment, Version: 0.7.2 RC2, 2012; p. 158. Available online: www.spatialecology.com/gme (accessed on 17 February 2014). 
34. Hirzel, A.H.; Guisan, A. Which is the optimal sampling strategy for habitat suitability modelling. Ecol. Model. 2002, 157, 331-341.

35. Mizuno, N. Sansai/Kinomi (Edible Wild Plants in Japan). In Yama-Kei Pocket Guide 4 (in Japanese); Yama-Kei Publishers Co., Ltd: Tokyo, Japan, 1999; p. 281.

36. Miller, J.; Franklin, J. Modeling the distribution of four vegetation alliances using generalized linear models and classification trees with spatial dependence. Ecol. Model. 2002, 157, 227-247.

37. Rennó, C.D.; Nobre, A.D.; Cuartas, L.A.; Soares, J.V.; Hodnett, M.G.; Tomasella, J.; Waterloo, M.J. HAND, a new terrain descriptor using SRTM-DEM: Mapping terra-firme rainforest environments in Amazonia. Remote Sens. Environ. 2008, 112, 3469-3481.

38. Tarboton, D.G. A new methods for the determination of flow directions and upslope areas in grid digital elevation models. Water Resour. Res. 1997, 33, 309-319.

39. Kawabata, Y. Shokusei: Tadami-machi-no-Shinrin-ya-Sougen (Vegetation: Forest and Grassland in Tadami Town) (in Japanese). In Aizu Tadami no Shizen: Shokubutu-hen (Nature in Aizu-Tadami: Vegetation); Editorial Committee of the History of Tadami: Tadami-machi, Japan, 2001; pp. 52-71.

40. Whittingham, M.J.; Stephens, P.A; Bradbury, R.B.; Freckleton, R.P. Why do we still use stepwise modelling in ecology and behaviour? J. Anim. Ecol. 2006, 75, 1182-1189.

41. Murtaugh, P.A. Performance of several variable-selection methods applied to real ecological data. Ecol. Lett. 2009, 12, 1061-1068.

42. Fielding, H.A.; Bell, F.J. A review of methods for the assessment of prediction errors in conservation presence/absence models. Environ. Conserv. 1997, 24, 38-49.

43. Manel, S.; Williams, C.H.; Ormerod, J.S. Evaluating presence-absence models in ecology: The need to account for prevalence. J. Appl. Ecol. 2001, 38, 921-931.

44. Freeman, E.; Moisen, G. A comparison of the performance of threshold criteria for binary classification in terms of predicted prevalence and kappa. Ecol. Model. 2008, 217, 48-58.

45. Pearce, J.; Ferrier, S. Evaluating the predictive performance of habitat models developed using logistic regression. Ecol. Model. 2000, 133, 225-245.

46. Sato, T. Comparative life history of aspidiaceous ferns in northern Japan with reference to fertility during sporophyte development in relation to habitats. Bot. Mag. Tokyo 1985, 98, 371-381.

47. Landi, M.; Angiolini, G. Ecological responses of Osmunda regalis to forest canopy cover and grazing. Am. Fern J. 2010, 100, 137-147.

48. Suzuki, W.; Osumi, K.; Masaki, T. Disturbance regimes and community structures of a riparian and an adjacent terrace stand in the Kanumazawa Riparian Research Forest, northern Japan. For. Ecol. Manage. 2002, 157, 285-301.

49. Kawanishi, M.; Sakio, H.; Kubo, M.; Shimano, K.; Ohno, K. Effect of micro-landforms on forest vegetation differentiation and life-form diversity in the Chichibu Mountains, Kanto District, Japan. Veg. Sci. 2006, 23, 13-24.

50. Shimada, Y. Ecology of bracken (Pteridium aquilinum (L.) Kuhn): Dynamics of bracken population in native grassland (in Japanese with English abstract). Weed Res. Jpn. 1962, 1, $70-77$. 
51. Miyama, T.; Goto, Y. The soil conservation function of bracken fern (Pteridium aquilinum Kuhn var. latiuschlum Underw) after the forest fire (in Japanese with English abstract). Jpn. Soc. Reveg. Technol. 2000, 26, 36-41.

52. Takahashi, Y.; Ide, Y.; Kobayashi, H.; Hayasaka, K. Effects of cutting management on the vegetation changes of the Zoysia-Pteridium-type pasture in western Honshu, Japan (in Japanese with English abstract). Jpn. J. Grassl. Sci. 2008, 54, 230-235.

53. Yukawa, Y. Henyou Suru Sanson (Changing Mountainous Villages in Japan) (in Japanese); Japan Editors School Publishing Division: Tokyo, Japan, 1991; p. 328.

54. Shimokawa, K. Geomorphic study of avalanche chute in the upper drainage basin of the Tadami River (in Japanese with English abstract). Geogr. Rev. Jpn. 1980, 53, 171-188.

55. Aiura, H. Erosive phenomenon in heavy snow mountainous regions in Japan. J. For. Res. 2002, 7 , $57-66$.

56. Matsuura, T.; Suzuki, W. Analysis of topography and vegetation distribution using a digital elevation model: Case study of a snowy mountain basin in northeastern Japan. Landsc. Ecol. Eng. 2013, 9, 143-155.

57. Miida, K. Zenmai (royal fern) production and its village sustaining function in the Tohoku district of Japan (in Japanese with English abstract). Geogr. Rev. Jpn. 1974, 47, 370-386.

58. Fukamachi, K.; Oku, H.; Nakashizuka, T. The change of a satoyama landscape and its causality in Kamiseya, Kyoto Prefecture, Japan between 1970 and 1995. Landsc. Ecol. 2001, 16, 703-717.

59. Osumi, K.; Ikeda, S.; Okamoto, T. Vegetation patterns and their dependency on site conditions in the pre-industrial landscape of north-eastern Japan. Ecol. Res. 2003, 18, 753-765.

60. Nagaike, T.; Kamitani, T. Factors affecting changes in a landscape structure dominated by both primary and coppice forests in the Fagus crenata forest region of central Japan. J. For. Res. 1997, 2, 193-198.

61. Miyamoto, A.; Sano, M. The influence of forest management on landscape structure in the cool-temperate forest region of central Japan. Landsc. Urban Plan. 2008, 86, 248-256.

62. Albers, H.; Robinson, E. A review of the spatial economics of non-timber forest product extraction: Implications for policy. Ecol. Econ. 2013, 92, 87-95.

63. Nackoney, J.; Rybock, D.; Dupain, J.; Facheux, C. Coupling participatory mapping and GIS to inform village-level agricultural zoning in the Democratic Republic of the Congo. Landsc. Urban Plan. 2013, 110, 164-174.

(C) 2014 by the authors; licensee MDPI, Basel, Switzerland. This article is an open access article distributed under the terms and conditions of the Creative Commons Attribution license (http://creativecommons.org/licenses/by/3.0/). 